\title{
O Uso do Analisador de Anestésicos Inalatórios como Método de Detecção de Falha no Aparelho de Anestesia e Prevenção de Consciência no Per-Operatório. Relato de Caso *
}

\author{
Inhalational Anesthetics Analyzer as a Method to Detect Anesthesia \\ Machine Failures and Prevent Intraoperative Awareness. Case Report
}

Marcos Guilherme Cunha Cruvinel, TSA ${ }^{1}$; Carlos Henrique Viana de Castro, TSA ${ }^{2}$; José Roberto de Rezende Costa, TSA ${ }^{1}$

\begin{abstract}
RESUMO
Cruvinel MGC, Castro CHV, Costa JRR - O Uso do Analisador de Anestésicos Inalatórios como Método de Detecção de Falha no Aparelho de Anestesia e Prevenção de Consciência no Per-Operatório. Relato de Caso
\end{abstract}

JUSTIFICATIVA E OBJETIVOS: A consciência per-operatória é uma rara, mas grave, complicação da anestesia geral. O mau funcionamento do aparelho de anestesia é uma das diversas causas das complicações anestésicas, dentre elas a consciência per-operatória. O objetivo deste relato é mostrar um caso em que o uso do analisador de anestésicos inalatórios proporcionou o diagnóstico de uma falha no aparelho de anestesia que poderia ter causado consciência no per-operatório.

RELATO DO CASO: Paciente do sexo feminino, 38 anos, 55 $\mathrm{kg}$, estado físico ASA I, portadora de carcinoma na mama direita, admitida para mastectomia radical e reconstrução mamária com retalho miocutâneo. Foi realizada punção peridural em $T_{8^{-}} T_{9}$ com agulha $17 \mathrm{G}$ com introdução de catetere administração de ropivacaína a $0,2 \%$. Seguiu-se indução de anestesia geral com início de vaporização de sevoflurano. Apesar dos outros parâmetros de monitorização não terem acusado achados de relevância, o analisador de anestésicos inalatórios não identificou a presença de sevoflurano, o que conduziu ao diagnóstico de um vazamento no vaporizador.

CONCLUSÕES: A consciência per-operatória é uma complicação que, apesar de rara, é grave e deve ser prevenida. As falhas do equipamento de anestesia podem ser minimizadas por sua inspeção, com testes detalhados e rotineiros antes do seu uso. O analisador de anestésicos inalatórios é um monitor útil sempre que estes estejam sendo utilizados e um instrumento útil para detectar precocemente falhas no equipamento de anestesia, como exemplificado no caso relatado.

Unitermos: COMPLICAÇÕES: consciência per-operatória; EQUIPAMENTOS: analisador de anestésicos inalatórios

\footnotetext{
* Recebido do (Received from) Departamento de Anestesiologia do Hospital Mater Dei, Belo Horizonte, MG

1. Anestesiologista do Hospital Mater Dei

2. Coordenador do Dept ${ }^{\circ}$ de Anestesiologia do Hospital Vera Cruz - Life Center
}

Apresentado (Submitted) em 24 de outubro de 2002

Aceito (Accepted) para publicação em 18 de fevereiro de 2003

Endereço para correspondência (Correspondence to)

Dr. Marcos Guilherme Cunha Cruvinel

Rua Simão Irffi, 86/301 Bairro Coração de Jesus

30380-270 Belo Horizonte, MG

E-mail: cruvinel@bis.com.br

(C) Sociedade Brasileira de Anestesiologia, 2003

\author{
SUMMARY \\ Cruvinel MGC, Castro CHV, Costa JRR - Inhalational Anesthe- \\ tics Analyzer as a Method to Detect Anesthesia Machine Failu- \\ res and Prevent Intraoperative Awareness. Case Report
}

BACKGROUND AND OBJECTIVES: Although rare, intraoperative awareness is a severe general anesthesia complication. Anesthesia machine malfunction is one of several causes for anesthetic complications, among them intraoperative awareness. This report aimed at showing a case where the volatile anesthetic monitor has detected machine malfunction which could have led to intraoperative awareness.

CASE REPORT: Female patient, 38 years old, $55 \mathrm{~kg}$, physical status ASA I, with right breast cancer, admitted for radical mastectomy and immediate myocutaneous flap reconstruction. Epidural puncture was performed at $T_{8}-T_{9}$ with a 17-gauge Tuohy epidural needle followed by the introduction of 18-gauge epidural catheter and administration of $0.2 \%$ ropivacaine. General anesthesia was then induced, followed by sevoflurane vaporization. Although other monitoring parameters have not detected relevant findings, the inhalational anesthetic monitor has not identified the presence of sevoflurane, thus allowing the diagnostic of vaporizer leakage.

CONCLUSIONS: Although rare, intraoperative awareness is a severe complication which should be prevented. Routine and thorough anesthesia equipment inspection before its use may minimize failures. The inhalational anesthetics monitor is useful whenever inhaled anesthetics are being used and may early detect anesthesia machine failures as in this case report.

Key Words: COMPLICATIONS: intraoperative awareness; EQUIPMENTS: inhalational anesthetics monitor

\section{INTRODUÇÃO}

$\bigcup$ ma das complicações da anestesia geral é a consciência per-operatória. Sua incidência na população em geral é de $0,2 \%$ a $0,4 \%{ }^{1-6}$. Embora rara, esta complicação é grave com potenciais seqüelas psicológicas ${ }^{7}$.

O aparelho de anestesia é o equipamento mais intimamente relacionado à prática anestésica. Seu funcionamento adequado é crucial para a segurança dos pacientes, pois seu mau funcionamento é uma das causas de acidentes anestésicos. A consciência per-operatória pode ser conseqüência de problemas com o equipamento de anestesia ${ }^{8,9}$.

A análise dos gases anestésicos pode ser útil durante qualquer procedimento em que a anestesia inalatória esteja sendo usada. As medidas dos agentes voláteis protegem contra sobredoses acidentais ou doses insuficientes secundárias ao mau funcionamento do vaporizador e facilitam o manuseio per-operatório nas anestesias inalatórias. Não existem contra-indicações ao seu uso ${ }^{10,11}$. 
O objetivo deste relato é mostrar um caso onde o uso do analisador de gases halogenados levou ao diagnóstico de uma falha no aparelho de anestesia que poderia ter levado à consciência no per-operatório.

\section{RELATO DO CASO}

Paciente do sexo feminino, 38 anos, $55 \mathrm{~kg}$, estado físico ASA I, portadora de tumor na mama direita admitida para mastectomia radical e reconstrução mamária com retalho miocutâneo. Não recebeu medicação pré-anestésica. A monitorização foi feita com eletrocardiograma contínuo $\left(D_{\|}\right.$e $\left.V_{5}\right)$, oxímetro de pulso, pressão arterial automática não invasiva, capnógrafo, monitor de gases anestésicos, pressão de via aérea e diurese através de sondagem vesical de demora. Após venóclise periférica com cateter 18G, foram administrados $2 \mathrm{mg}$ de midazolam e, com a paciente em posição sentada, realizada punção peridural em $\mathrm{T}_{8}-\mathrm{T}_{9}$ com agulha $17 \mathrm{G}$. Após dose teste com 40 mg de lidocaína a $2 \%$ com epinefrina $1: 200.000$, foram administrados $20 \mathrm{ml}$ de ropivacaína a $0,2 \%$. Seguiu-se a introdução $(3 \mathrm{~cm})$ de cateter peridural $18 \mathrm{G}$ e pelo mesmo, após dose teste com $40 \mathrm{mg}$ de lidocaína a $2 \%$ com epinefrina $1: 200.000$, foram injetados mais $20 \mathrm{ml}$ de ropivacaína a $0,2 \%$. A altura do bloqueio obtida foi $\mathrm{T}_{2}$, avaliada pala pesquisa de temperatura. Aindução anestésica foi feita com $20 \mu \mathrm{g}$ de sufentanil, $150 \mathrm{mg}$ de propofol e $50 \mathrm{mg}$ de rocurônio. A intubação traqueal foi feita através de laringoscopia convencional, utilizando-se um tubo traqueal de $7,5 \mathrm{~mm}$. A paciente foi conectada ao aparelho de anestesia (Takaoka 2605 , ventilador 677 , vaporizador 1415 , rotâmetro 1822 e filtro valvular 3364) e iniciada ventilação controlada com fluxo de $1 \mathrm{~L}$. $\mathrm{min}^{-1}$ de oxigênio. A freqüência cardíaca permaneceu nos mesmos níveis pré-indução, a pressão arterial apresentou diminuição de $20 \%$, a expansibilidade torácica era normal e simétrica, assim como eram normais, a ausculta respiratória e a pressão de vias aéreas. A saturação arterial manteve-se $100 \%$ e o capnógrafo mostrava uma fração expirada de $30 \mathrm{mmHg}$ com curva de capnografia normal. Foi iniciada a anti-sepsia da região a ser operada e a colocação dos campos cirúrgicos. Estava sendo utilizado um vaporizador universal preenchido com $100 \mathrm{ml}$ de sevoflurano. Foi iniciado, então, um fluxo de $100 \mathrm{ml}$. $\mathrm{min}^{-1}$ de oxigênio pelo vaporizador. Uma vez que o analisador de gases halogenados mostrava ausência de sevoflurano, o fluxo de oxigênio foi aumentado para 2 L. $\mathrm{min}^{-1}$ e o fluxo para o vaporizador para $200 \mathrm{ml}$. $\mathrm{min}^{-1}$. Como estas medidas não foram eficazes, foi iniciada infusão contínua de propofol $\left(3,6 \mathrm{mg} \cdot \mathrm{kg}^{-1} \cdot \mathrm{h}^{-1}\right)$ e uma análise do aparelho de anestesia refeita à procura de uma causa para a ausência de vaporização. Havia um borbulhamento adequado, mas percebeu-se que o vaporizador não estava devidamente vedado na sua extremidade superior, ou seja, no local de abastecimento. Com o posicionamento adequado da tampa, imediatamente o analisador de gases halogenados passou a ter leitura de sevoflurano. A revisão do monitor mostrou que transcorreram-se 5 minutos entre a primeira leitura de $\mathrm{CO}_{2} \mathrm{e}$ a primeira leitura de sevoflurano. A cirurgia transcorreu sem intercorrências e a paciente evoluiu bem. A paciente foi entrevistada no pós-operatório e foram feitas as seguintes perguntas:

1. Qual sua última lembrança antes de dormir?

2. Qual sua primeira lembrança depois da cirurgia?

3. Você se lembra de algo neste espaço de tempo?

As respostas foram as seguintes:

1. "O anestesista falando que a peridural tinha acabado e eu já iria dormir".

2. "O anestesista falando que a cirurgia já tinha acabado e perguntando se eu estava sentido dor".

3. "Não".

\section{DISCUSSÃo}

A anestesia geral implica, além da ausência de dor, controle de reflexos neurovegetativos e relaxamento muscular, os critérios inconsciência e amnésia. Vários agentes podem ser usados para atingir estes objetivos, por exemplo, uma concentração alveolar de sevoflurano de 0,6\% (0,3 CAM) é necessária para abolir a resposta verbal aos comandos em $50 \%$ dos pacientes ${ }^{7}$. Pacientes não curarizados podem apresentar movimentos quando conscientes durante a anestesia geral, no entanto, pacientes curarizados podem estar conscientes ou apresentar lembranças per-operatórias, mesmo sem movimentação $^{7,12-16}$. No caso em discussão, era exatamente este o cenário, ou seja, uma paciente curarizada e sem uma dose suficiente de sevoflurano para abolir a consciência. Os opióides, como o sufentanil utilizado neste caso, proporcionam analgesia e podem até produzir inconsciência se usados em altas doses, entretanto dificilmente promovem amnésia, especialmente em baixas doses ${ }^{17}$. O propofol produz amnésia e hipnose de maneira eficaz, entretanto, sua rápida captação pelos tecidos e metabolismo faz com o término de seu efeito seja mais rápido que o rocurônio ${ }^{18,19}$. Em um estudo da incidência de memória explícita per-operatória em pacientes submetidos à anestesia geral, Ashmawi e col. descreveram sete casos em que ela ocorreu ${ }^{13}$. A exemplo do caso em tela, em cinco casos a combinação paralisia muscular e plano anestésico superficial estava presente ${ }^{13}$. Nota-se, no caso descrito, a real possibilidade de consciência per-operatória.

A consciência durante a cirurgia pode causar, entre outros, síndrome de estresse pós-traumático, distúrbios do sono e ansiedade $^{7,12}$. Esta síndrome, inicialmente descrita em combatentes de guerra e vítimas de catástrofes, foi descrita em pacientes que acordaram durante a anestesia, estando paralisados por bloqueador neuromuscular, e compreende pesadelos repetitivos, ansiedade e irritabilidade generalizadas e preocupação com a morte ${ }^{12}$. Há um aumento no número de pedidos de indenização por parte daqueles que alegam terem acordado durante anestesia geral e retiveram lembranças daquele período ${ }^{12}$. Em um estudo da Sociedade Ameri- 
cana de Anestesiologistas foram encontrados 79 processos entre $4.183(1,9 \%)$ envolvendo consciência durante anestesia geral ${ }^{20}$

Aconsciência per-operatória está relacionada com a superficialização do plano anestésico ${ }^{12}$. A forma mais comum de se diagnosticar a superficialização do plano anestésico é a partir de sinais clínicos ${ }^{12}$. Os sinais clínicos para detectá-la são movimentação do paciente, hipertensão arterial, taquicardia, diaforese, midríase, lacrimejação e salivação ${ }^{7,12}$. Na série de Ashmawi e col., $71 \%$ dos pacientes apresentaram pelo menos um destes sinais clínicos ${ }^{13}$. Entretanto, a utilização de drogas como opióides, colinérgicos, anticolinérgicos, $\beta$-bloqueadores ou vasodilatadores entre outras razões fazem dos sinais clínicos um método impreciso de diagnóstico. No estudo da Sociedade Americana de Anestesiologistas, a maioria dos 79 pacientes que apresentaram consciência no per-operatório não apresentaram hipertensão arterial, taquicardia e movimentação, denotando a relativa ineficiência destes sinais autonômicos como monitores de consciência ${ }^{20}$

Dentre os métodos para monitorização de profundidade de anestesia e/ou consciência estariam a eletromiografia, a eletroencefalografia, o índice bispectral (BIS), os potenciais evocados e o monitor de gases anestésicos ${ }^{7}$. Entre estes destaca-se o BIS como um monitor especificamente desenvolvido para determinar o estado de consciência e, portanto, o mais útil para análise do grau de hipnose. A ferramenta mais aceita para o diagnóstico pós-operatório da consciência per-operatória é a entrevista de acordo com protocolo de Brice modificado por Sandin e col. (Quadro I) ${ }^{6,21}$. Foram feitas perguntas semelhantes à paciente cujas respostas foram negativas para presença de consciência per-operatória.

Quadro I - Protocolo de Brice Modificado por Sandin ${ }^{6,21}$

1. Qual sua última lembrança antes de dormir?

2. Qual sua primeira lembrança depois do término da cirurgia?

3. Você consegue se lembrar de algo neste intervalo?

4. Você se lembra de ter sonhado durante a cirurgia?

5. Qual foi a pior coisa da cirurgia?

A monitorização da fração expirada de anestésicos voláteis ao monitorar a profundidade da anestesia ajuda a reduzir erros causados por vaporizadores vazios, mal funcionantes, desconectados e outras falhas de equipamentos, como no caso em tela ${ }^{7}$. A associação da analgesia proporcionada pela administração de anestésico local no espaço peridural e de opióide por via venosa tornou improvável que a paciente apresentasse sinais autonômicos indicativos de consciên- cia. Por sua vez, o uso de bloqueador neuromuscular impediria que a movimentação indicasse a consciência. Com isso acreditou-se que a monitorização da fração expirada de anestésicos voláteis tenha sido fundamental na detecção precoce da falha do equipamento e, assim, preveniu esta grave complicação. Essa capacidade do monitor de gases halogenados de avaliar a profundidade da anestesia é baseada no conceito, desenvolvido por Eger e col., de que a concentração alveolar do anestésico reflete sua pressão parcial no cérebro ${ }^{22}$. Isso fez da concentração alveolar mínima (CAM) um dos mais úteis e importantes conceitos em anestesia ${ }^{23}$. Para anestésicos venosos, a relação entre a taxa de infusão e a concentração plasmática é muito variável fazendo com que o conceito análogo da CAM para anestésicos venosos, a taxa de infusão mínima, tenha valor reduzido ${ }^{7,24}$.

Apesar de vários progressos na segurança dos equipamentos de anestesia, suas falhas continuam sendo uma causa significativa de acidentes em anestesia ${ }^{8,9,12,24}$. A inspeção de rotina do equipamento de anestesia antes de seu uso é fundamental ${ }^{12}$. O procedimento específico depende do equipamento a ser usado. Os riscos mais freqüentes são: hipóxia, hipoventilação, hipercapnia, hiperventilação, pressão alta de via aérea, sobredose de anestésicos e fornecimento insuficiente de anestésicos ${ }^{12,24}$. No caso em questão, trata-se do fornecimento insuficiente de anestésicos, cujas principais causas são: diminuição do fluxo de óxido nitroso, vazamento no vaporizador, vaporizador vazio, agente incorreto no vaporizador, montagem incorreta do vaporizador e diluição pelo fluxo de ar propulsor. O problema identificado foi um grande vazamento no vaporizador causado pelo mau posicionamento da tampa. Uma inspeção correta e detalhada do equipamento de anestesia antes de seu uso poderia ter prevenido sua falha. O anestesiologista responsável pelo caso realizou testes para verificação de vazamento no circuito de anestesia e funcionamento adequado do ventilador, entretanto, o vaporizador não foi verificado.

O monitor de anestésicos inalatórios é útil sempre que anestésicos inalatórios estejam sendo utilizados, capaz de prevenir a consciência per-operatória e detectar precocemente faIhas no equipamento de anestesia, como exemplificado no caso relatado. No entanto, as falhas do equipamento de anestesia podem ser minimizadas por sua inspeção e testes detalhados e rotineiros antes do seu uso. É importante ressaltar que esta verificação deve ser completa, incluindo o ventilador, rotâmetro, circuito e vaporizador, uma vez que em alguns aparelhos de anestesia o funcionamento adequado do ventilador não garante e nem promove detecção de falhas do vaporizador. 


\section{Inhalational Anesthetics Analyzer as a Method to Detect Anesthesia Machine Failures and Prevent Intraoperative Awareness. Case Report}

Marcos Guilherme Cunha Cruvinel, TSA, M.D.; Carlos Henrique Viana de Castro, TSA, M.D.; José Roberto de Rezende Costa, TSA, M.D.

\section{INTRODUCTION}

Intraoperative awareness is a general anesthesia complication, with an incidence of $0.2 \%$ to $0.4 \%{ }^{1-6}$. Although rare, it is a severe complication with potential psychological sequelae ${ }^{7}$. Anesthesia machine is the equipment most closely related to the anesthetic practice. Its proper functioning is critical for patients' safety because its malfunction is a cause for anesthetic accidents. Intraoperative awareness may be a consequence of problems with the anesthesia machine ${ }^{8,9}$.

Anesthetic gases analysis may be useful during any procedure under inhalational anesthesia. Volatile agent measurements protect against accidental overdoses or insufficient doses secondary to vaporizer malfunctioning, and help intraoperative handling during inhalational anesthesia. There are no counterindications for its use ${ }^{10,11}$.

This report aimed at showing a case where the halogenate gases analyzer has led to the diagnosis of an anesthesia machine failure which could have caused intraoperative awareness.

\section{CASE REPORT}

Female patient, 38 years old, $55 \mathrm{~kg}$, physical status ASA I, with right breast cancer and admitted for radical mastectomy with immediate myocutaneous flap reconstruction. Patient was not premedicated. Monitoring consisted of continuous ECG $\left(D_{\|}\right.$and $\left.V_{5}\right)$, pulse oximetry, non-invasive automatic blood pressure, capnographer, anesthetic gases analyzer, airway pressure and diuresis through indwelling vesical catheter. After peripheral venoclysis with $18 \mathrm{G}$ catheter, $2 \mathrm{mg}$ midazolam were administered and puncture was performed at $\mathrm{T}_{8}-\mathrm{T}_{9}$ with a $17 \mathrm{G}$ needle, with the patient in the sitting position. After a test dose with $40 \mathrm{mg}$ of $2 \%$ lidocaine with epinephrine $1: 200,000,20 \mathrm{ml}$ of $0.2 \%$ ropivacaine were administered, followed by the introduction of an $18 \mathrm{G}$ epidural catheter. After a test dose with $40 \mathrm{mg}$ of $2 \%$ lidocaine with epinephrine $1: 200000$, additional $20 \mathrm{ml}$ of $0.2 \%$ ropivacaine were injected. Blockade height was $\mathrm{T}_{2}$ evaluated for temperature measurements. Anesthesia was induced with $20 \mu \mathrm{g}$ sufentanil, $150 \mathrm{mg}$ propofol and $50 \mathrm{mg}$ rocuronium. Tracheal intubation was achieved through conventional laryngoscopy, using a $7.5 \mathrm{~mm}$ tracheal tube. Patient was connected to the anesthesia machine (Takaoka 2605, ventilator 677, vaporizer 1415, rotameter 1822 and valve filter 3364) and controlled ventilation with $1 \mathrm{~L}$. $\mathrm{min}^{-1}$ oxygen was started. Heart rate remained in baseline values, blood pressure was $20 \%$ de- creased and chest expansion was normal and symmetric; respiratory auscultation and airway pressure were also normal. Arterial saturation remained $100 \%$ and the capnographer showed $30 \mathrm{mmHg}$ expired fraction with normal capnography curve. Surgical site was disinfected and covered with surgical drapes. A universal vaporizer filled with $100 \mathrm{ml}$ sevoflurane was being used. Oxygen flow of $100 \mathrm{ml}^{.} \mathrm{min}^{-1}$ was then started through the vaporizer. Since the halogenate gases analyzer could not detect sevoflurane, oxygen flow was increased to 2 L. $\mathrm{min}^{-1}$ and vaporizer flow to $200 \mathrm{ml}^{\mathrm{min}} \mathrm{min}^{-1}$. Since those measures were ineffective, propofol continuous infusion (3.6 $\left.\mathrm{mg} \cdot \mathrm{kg}^{-1} \cdot \mathrm{h}^{-1}\right)$ was started and the anesthesia machine was reanalyzed in search for a cause for the lack of vaporization. There was adequate bubbling, but the vaporizer was not duly sealed at its upper edge, that is on the supply side. After the adequate lid positioning, the halogenate gases analyzer started reading sevoflurane. Monitor review has shown that 5 minutes were elapsed from the first $\mathrm{CO}_{2}$ reading to the first sevoflurane reading. Surgery went on without intercurrences and patient evolved satisfactorily. The following questions were asked to the patient in the postoperative period:

1. What was your last remembrance before falling asleep?

2. What was your first postoperative remembrance?

3. Do you remember something during this time period?

The answers were as follows:

1. "The anesthesiologist saying that epidural anesthesia was over and that I would fall asleep".

2. "The anesthesiologist saying that surgery was over and asking whether I was feeling pain".

3. "No".

\section{DISCUSSION}

In addition to absence of pain, anesthesia implies neurovegetative reflexes control and muscle relaxation, that is, unconsciousness and amnesia. Several agents may be used for such end, for example, $0.6 \%$ sevoflurane alveolar concentration (0.3 MAC) is needed to abolish verbal response to commands in $50 \%$ of patients ${ }^{7}$. Non-curarized patients may move when aware during general anesthesia, however, curarized patients may be aware or have intraoperative remembrances without moving ${ }^{7,12-16}$. In our case, this was exactly the scenario, that is, a curarized patient without the adequate sevoflurane dose to abolish awareness. Opioids, like sufentanil used in our case, induce analgesia and may even induce unconsciousness if used in high doses, however seldom produce amnesia, especially in low doses ${ }^{17}$. Propofol induces effective amnesia and hypnosis, however its fast uptake by tissues and metabolism make its duration shorter as compared to rocuronium ${ }^{18,19}$. A study by Ashmawi et al. has described seven cases of intraoperative explicit memory in patients submitted to general anesthesia 13. Similarly to our case, five cases presented the combination of muscle paralysis and superficial anesthesia ${ }^{13}$. The de- 
scribed case clearly shows the real possibility of intraoperative awareness.

Awareness during surgery may cause post-trauma stress syndrome, sleep abnormalities and anxiety, among others 7,12 . This syndrome, firstly described in war fighters and victims of catastrophes, was also described in patients who woke up during anesthesia but were paralyzed by neuromuscular blockers, and includes repetitive nightmares, generalized anxiety and irritability, and concern with death ${ }^{12}$. There is an increase in indemnities requests on part of those claiming awareness during general anesthesia and keeping remembrances from that period ${ }^{12}$. In a study of the American Society of Anesthesiologists, 79 out of 4,183 law suits $(1.9 \%)$ were found involving awareness during general anesthesia $^{20}$.

Intraoperative awareness is related to superficial anesthesia

${ }^{12}$. Most common method to diagnose superficial anesthesia is to evaluate clinical signs ${ }^{12}$, which are: patients' movement, arterial hypertension, tachycardia, diaphoresis, tearing and salivation ${ }^{7,12}$. In Ashmawy et al. series, $71 \%$ of patients had at least one of those clinical signs ${ }^{13}$. However, drugs such as opioids, cholinergics, anti-cholinergics, $\beta$-blockers or vasodilators, among other reasons, make clinical signs an imprecise diagnostic method. In the study of the American Society of Anesthesiologists, most 79 patients with intraoperative awareness had no arterial hypertension, tachycardia or movements, showing the relative inefficiency of those autonomic signs as awareness monitors ${ }^{20}$. Electromyography, electroencephalography, bispectral index (BIS), evoked potentials and anesthetic gases analyzer are some of the methods to monitor anesthetic depth and/or awareness ${ }^{7}$. Special attention should be given to BIS as a monitor specifically developed to determine consciousness level, thus the most useful to determine the level of hypnosis. The most accepted tool for postoperative diagnosis of intraoperative awareness is the interview, according to Brice's protocol modified by Sandin et al. (Chart I) ${ }^{6,21}$. Similar questions were asked to our patients and the answers were negative for the presence of intraoperative awareness.

Chart I - Brice's Protocol Modified by Sandin ${ }^{6,21}$

1. What was your last remembrance before falling asleep?

2. What was your first remembrance after surgery?

3. Can you remember anything during this time period?

4. Do you remember dreaming during surgery?

5. What was the worst thing about the surgery?

Volatile anesthetics expired fraction monitoring to monitor anesthetic depth helps decreasing damages caused by empty, malfunctioning or disconnected vaporizers, or by other equipment failures, as in our case ${ }^{7}$. The association of epidural local anesthetic analgesia and intravenous opioids made unlikely to the patient to present autonomic signs of awareness. On the other hand, neuromuscular blockers would prevent movements of indicating awareness. So, we believe that volatile anesthetics expired fraction monitoring was critical for the early detection of equipment failure, thus preventing such severe complication. This halogenate gases monitor ability to evaluate anesthetic depth is based on the concept developed by Eger et al., that alveolar anesthetic concentration reflects its partial brain pressure ${ }^{22}$. This has made minimum alveolar concentration (MAC) one of the most useful and important concepts in anesthesia ${ }^{23}$.

The ratio between infusion rate and plasma concentration is widely variable for intravenous anesthetics, thus decreasing the usefulness of the MAC-analog concept for intravenous anesthetics, that is, minimum infusion rate ${ }^{7,24}$.

In spite of many progresses in anesthesia equipment safety, its failures continue to be a significant cause for anesthetic accidents $^{8,9,12,24}$. Routine inspection of the anesthesia machine before its use is critical ${ }^{12}$. The specific procedure depends on the equipment. Most frequent risks are: hypoxia, hypoventilation, hypercapnia, hyperventilation, high airway pressure, anesthetic overdose and insufficient anesthetic supply ${ }^{12,24}$. Our case was insufficient anesthetic supply, the major causes of which are: nitrous oxide flow decrease, vaporizer leakage, empty vaporizer, wrong agent in the vaporizer, vaporizer incorrect assembly and dilution by propelling air flow. Our problem was a major vaporizer leakage caused by the lack of lid. A correct and thorough inspection of the anesthesia machine before its use could have prevented this failure. The anesthesiologist in charge of the case has performed tests to check leakages in the anesthetic circuit and adequate ventilator operation; the vaporizer, however, was not checked.

Inhalational anesthetics monitor is useful whenever inhalational anesthetics are being used and is able to prevent intraoperative awareness and to early detect anesthesia machine failures, as exemplified by our case. However, anesthesia equipment failures may be minimized by detailed routine inspections and tests before its use. It is important to highlight that this should be a thorough inspection, including ventilator, rotameter, circuit and vaporizer, since the adequate operation of the ventilator does not assure or promote vaporizer failures detection in some anesthesia machines.

\section{REFERÊNCIAS - REFERENCES}

01. Wennervirta J, Ranta SOV, Hynynen M - Awareness and recall in outpatient anesthesia. Anesth Analg, 2002;95:72-77.

02. Jones JG - Perception and memory during general anesthesia. Br J Anesth, 1994;73:31-37.

03. Liu WH, Thorp TA, Graham SG et al - Incidence of awareness with recall during general anesthesia. Anesthesia, 1991;46: 435-437.

04. Nordstrom O, Engstrom AM, Persson S et al - Incidence of awareness in total i.v. anaesthesia based on propofol, alfentanil and neuromuscular blockade. Acta Anaesthesiol Scand, 1997; 41:978-984.

05. Ranta SOV, Laurila R, Saario J et al - Awareness with recall during general anesthesia: incidence and risk factors. Anesth Analg, 1998;86:1084-1089. 
06. Sandin R, Enlund G, Samuelsson P et al - Awareness during anaesthesia: a prospective case study. Lancet, 2000;355: 707-711.

07. Berrigan MJ - Awareness during anesthesia. Annual Meeting Lectures Refresher Courses, 2001;29:41-48.

08. Dorsch JA, Dorsch SE - The Anesthesia Machine, em: Dorsch JA, Dorsch SE - Understanding Anesthesia Equipment, $4^{\text {th }} \mathrm{Ed}$, Philadelphia, Lippincott Williams \& Wilkins, 1999;75-119.

09. Morgan Jr GE, Mikhail MS, Murray MJ - The Anesthesia Machine, em: Morgan Jr GE, Mikhail MS, Murray MJ - Clinical Anesthesiology, $3^{\text {rd }} \mathrm{Ed}$, Los Angeles, Lange, 2002;40-58.

10. Dorsch JA, Dorsch SE - Gas Monitoring, em: Dorsch JA, Dorsch SE - Understanding Anesthesia Equipment, $4^{\text {th }}$ Ed, Philadelphia, Lippincott Williams \& Wilkins, 1999;679-754.

11. Morgan Jr GE, Mikhail MS, Murray MJ - Patients Monitors, em: Morgan Jr GE, Mikhail MS, Murray MJ - Clinical Anesthesiology, $3^{\text {rd }}$ Ed, Los Angeles, Lange, 2002;86-126.

12. Ashmawi HA, Ruiz-Neto PP, Palmeira CCA et al - Memória explícita de eventos intra-operatórios durante anestesia geral. Rev Bras Anestesiol, 1997;47:261-272.

13. Ashmawi HA, Ruiz-Neto PP, Posso IP et al - Incidência de memória explícita de eventos intra-operatórios em pacientes submetidos a anestesia geral. Rev Bras Anestesiol, 1997;47: 371-380.

14. Lyons G, Macdonald R - Awareness during caesarian section. Anesthesia, 1991;46:62-64.

15. Phillips AA, McLean RF, Devitt JH et al - Recall of intraoperative events after general anesthesia and cardiopulmonary bypass. Can J Anesth, 1993;40:922-926.

16. Bogetz MS, Katz JA - Recall of surgery for major trauma. Anesthesiology, 1984;61:6-9.

17. Stoelting RK - Opioid Agonists and Antagonists, em: Stoelting RK - Pharmacology \& Physiology in Anesthetic Practice, $3^{\text {rd }} \mathrm{Ed}$, Philadelphia, Lippincott-Raven, 1999;77-112.

18. Stoelting RK - Nonbarbiturate Induction Drugs, em: Stoelting RK - Pharmacology \& Physiology in Anesthetic Practice, $3^{\text {rd }} E d$, Philadelphia, Lippincott-Raven, 1999;140-157.

19. Stoelting RK - Neuromuscular-Blocking Drugs, em: Stoelting RK - Pharmacology \& Physiology in Anesthetic Practice, $3^{\text {rd }} \mathrm{Ed}$, Philadelphia, Lippincott-Raven, 1999;182-223.

20. Domino KB, Poser KL, Caplan RA-Awareness during anaesthesia: a closed claims analysis. Anesthesiology, 1999;80: 1053-1061.

21. Brice DD, Hetherington RR, Utting JE - A simple study of awareness and dreaming anaesthesia. Br J Anaesth, 1970;42: 535-542.

22. Eger EL, Saidman LJ, Brandstater B - Minimum alveolar anesthetic concentration: A standard of anesthetic potency. Anesthesiology, 1965;26:756-763.
23. Stoelting RK - Pharmacokinetics and Pharmacodynamics of Injected and Inhaled Drugs, em: Stoelting RK - Pharmacology \& Physiology in Anesthetic Practice, $3^{\text {rd }}$ Ed, Philadelphia, Lippincott-Raven, 1999; 3-35.

24. Dorsch JA, Dorsch SE - Hazards of the Anesthesia Machines and Breathing Systems, em: Dorsch JA, Dorsch SE - Understanding Anesthesia Equipment, $4^{\text {th }}$ Ed, Philadelphia, Lippincott Williams \& Wilkins, 1999;339-440.

\section{RESUMEN}

Cruvinel MGC, Castro CHV, Costa JRR - El Uso del Analizador de Anestésicos Inhalatorios como Método de Detección de Falla en el Aparato de Anestesia y Prevención de Conciencia en el Per-Operatorio. Relato de Caso

JUSTIFICATIVA Y OBJETIVOS: La conciencia per-operatoria es una rara, y grave, complicación de la anestesia general. El mal funcionamiento del aparato de anestesia es una de las diversas causas de las complicaciones anestésicas, entre ellas está la conciencia per-operatoria. El objetivo de este relato es mostrar un caso en que el uso del Analizador de anestésicos inhalatorios proporcionó el diagnóstico de una falla en el aparato de anestesia que podría haber causado conciencia en el per-operatorio.

RELATO DE CASO: Paciente del sexo femenino, 38 años, 55 $\mathrm{kg}$, estado físico ASA I, portadora de carcinoma de la mama derecha, internada para mastectomia radical y reconstrucción mamaria con retazo miocutaneo. Fue realizada punción peridural en $T_{8}-T_{9}$ con aguja $17 \mathrm{G}$ con introducción de catéter y administración de ropivacaína a $0,2 \%$. Se continuó con inducción de anestesia general con inicio de vaporización de sevoflurano. A pesar que los otros parámetros de monitorización no hallan encontrado ni acusado nada de relevancia, el analizador de anestésicos inhalatorios no identificó la presencia de sevoflurano, lo que condujo al diagnóstico de un vaciamiento en el vaporizador.

CONCLUSIONES: La conciencia per-operatoria es una complicación que, a pesar de rara, es grave y debe ser prevenida. Las fallas del equipamiento de anestesia pueden ser minimizadas por su inspección, con tests detallados y de rutina antes de su uso. El analizador de anestésicos inhalatorios es un monitor útil siempre que éstos estén siendo utilizados, y también un instrumento útil para detectar precozmente fallas en el equipamiento de anestesia, como el ejemplo dado en el caso relatado. 